\title{
Application of Atterberg Model on Surface and Sub-Grade Soils for Foundation Mechanics and Design Suitability
}

\begin{abstract}
I.D. Edem*, M.E. Nkereuwem
*Department of Soil Science and Land Resources Management, University of Uyo, Nigeria. Department of Soil Science, Faculty of Agriculture, Federal University Dutse Jigawa State, Nigeria

Abstract: The study location is within the coastal plain sand of Akwa Ibom State. The area lies within a subhorizontal geomorphologic terrain with a measure of undulations arising from uneven surface area erosion. The study revealed that the soils are loose, coarse texture with $78-80 \%$ sandy fractions having single grain structure from unconsolidated materials of recent alluvial deposits. The soils are strongly acid in reaction with $p H$ values between 4.8 and 5.8 which could be attributed to leaching of the basic cations to lower depth. Organic carbon content ranged from moderately low $1.50 \%$ to high $2.38 \%$ due probably to high surface litter and vegetation cover. Since the ultimate bearing capacity depends upon the angle of internal fraction (d) and hence the penetration number $(N)$, it was related directly to the $N$ at profiles 1,2, 3 and 4 from the existing surface, cohesion value of $25 \mathrm{kN} / \mathrm{m}^{2}$ was applied and the allowable bearing pressure of $18.5 \mathrm{kN} / \mathrm{m}^{2}, 17.1 \mathrm{k} / \mathrm{Nm}^{2}$, $54 \mathrm{k} / \mathrm{Nm}^{2}$, and $66 \mathrm{kN} / \mathrm{m}^{2}$ were obtained for profiles 1, 2, 3 and 4 respectively by applying a factor of safety of 3.0. The higher the elevation, the higher the plasticity and the swelling potential; and the lower the bearing capacity and strength of the building sub-grade.
\end{abstract}

Keywords: Soil mechanics, coastal plain, bearing capacity, ecological condition

\section{INTRODUCTION}

Soil erosion is a phenomenon caused by multidimensional factors. Soil vulnerability to erosion focuses on climate and geotechnical soil characteristics as causatives. Soil erosion is a natural geological phenomenon resulting from the removal of soil particles by water or wind, and transporting them elsewhere. Some human activities can significantly increase erosion rates. Erosion is triggered by a combination of factors such as steep slopes, climate (e.g., long dry periods followed by heavy rainfall), inappropriate land use, land cover patterns (e.g., sparse vegetation) and ecological disasters (e.g., forest fires). Different indicators of soil erosion have been identified and it is a common opinion that the area actually affected by erosion is the best indicator for soil erosion. The factors which influence the rate of erosion are; rainfall, runoff, soil, slope, plant cover and the presence or absence of conservation measures (Muzik, 2002).

Erosion and land use change are very closely related. Rates of soil loss accelerate quickly to unacceptably high levels whenever land is misused. Soil erosion threatens soil fertility due to nutrient and organic matter loss, while also decreasing water quality through increased turbidity (Bonilla and Vidal, 2011). Many authors have reported that soil erosion and sediment movement have important influences on Carbon (C) sequestration potential in soils and ecosystems (Smith and Skinner, 2002). Therefore quantifying the impacts of climatic parameters on soil erosion has important implications to the understanding of their environmental impacts as well as the feedback of soil carbon dynamics to global warming. The vulnerability of a piece of land to soil erosion depends on the physical and chemical properties of the soil. Different types of soil have different physical and chemical properties. The texture, structure, water retention capability, etc. play important roles in determining whether the soil is susceptible to erosion or not. Climate determines the precipitation levels and wind velocity. More precipitation means more surface flow, and more surface flow means more area vulnerable to erosion by running water. This research aimed at providing detailed assessment of the suitability of the soils of the area, the sub-soil conditions and suggests relevant soil improvements where necessary as well as recommend appropriate foundation type and design parameters 


\section{METHODS OF INVESTIGATION}

\section{Field Work and Laboratory Methods}

Ground elevation ranges between 10-12 meters above mean sea level. The local geology is of the coastal plain sand consisting of extensive thickness of brownish, coarse to medium sand with subordinate clay and silt. The area is associated with luxuriant freshwater vegetation typical of a tropical rainforest. The hydrology of the study site is influenced by its high precipitation rate (Allen, 1965) with a mean annual rainfall exceeds $3000 \mathrm{~mm}$ over burden lithologic strata that over lie the aquifer, and at the sometimes undulating topography.

Numerous studies have been carried out on geotechnical properties of the subsoils generally (Oke et al., 2009, Youdeowei and Nwankwoala, 2013; Nwankwoala et al 2014). This study contains the results of surface and sub-grade soil investigations. Field work on the site of the proposed development was performed on the 6/12/15 with a reconnaissance survey where profile pits were dug (Fig 1). Auger sampling test side by side with the portable unconfined compression machine were utilized for the exploration of the ground surface in this investigation on the $22^{\text {nd }}$ and $23^{\text {rd }}$ December, 2015. The samples were submitted for subgrade complete test on the $28^{\text {th }}$ December, 2015.

The entire area was divided into four transects ( P1, P2, P3 and P4) and soil samples were collected using the grid format (Smith and Atkinson, 1975) and sampling location selected in such a manner as to adequately represent the ecological conditions of the study area. At the grid intersection, soil samples were collected by taking about five auger borings at random around the sampling station to depths of $0-15$ and $15-30 \mathrm{~cm}$ and compositing the soils from similar depth into well-labeled plastic bags. The quantity of composite samples collected was processed for analyses in the laboratory without sub-sampling in the field. This allowed for more accurate sub-samples that better represented the area and remove errors due to sample splitting and sub-sampling in the field. A total of thirty-six (36) top and bottom bulked samples and subgrade samples from four profiles were collected.

The analyses were performed on sub-samples of the air-dried soil samples using materials less than 2 $\mathrm{mm}$ diameter of the fine earth. Concentrations were expressed on a dry weight basis and the following physico-chemical parameters were determined: Soil $\mathrm{pH}$, electrical conductivity, organic carbon, total and mineral nitrogen, exchangeable cations, available phosphorus, and particle size analyses. Others include Atterberge limit and natural moisture content where Laboratory tests were carried out on representative sub-soil samples in accordance with British Standards (B.S) 1377, which are equivalent to the American Standards for Testing Materials (ASTM). The tests were conducted to enable the evaluation of the gradation, hydraulic conductivity (coefficient of permeability) and consistency (water absorbing and adsorbing ability) properties of the soil samples, as well as their classification. The samples obtained from the site were generally sand and clayey soils which mostly classified as CL under the unified soil classification system (USCS).

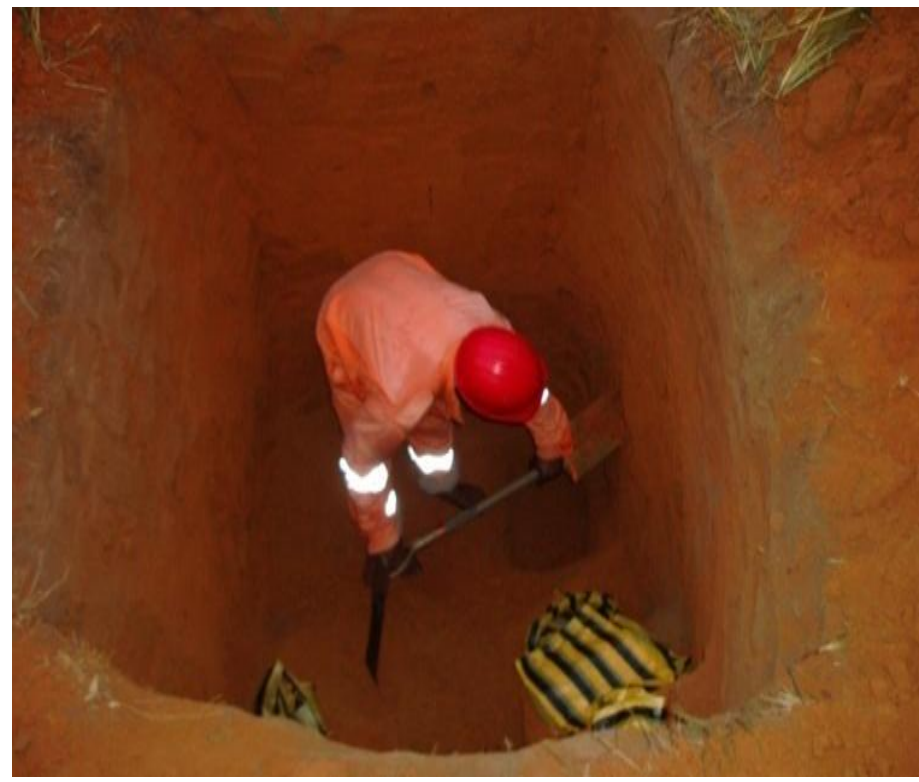

Fig 1. Showing profile pit sampling at one of the stations 


\section{A. Test Result of Sub-Grade and Materials}

The result of sieve and hydrometer analyses on the natural soil is presented in Figure 2 in form of particle size distribution. It shows that the soil is granular but has percentage passing the BS No. 200 sieve $(0.075 \mathrm{~mm})$ to be 29.1, 40.2, 30.2 and 25.64 for soil locations P1, P2, P3 and P4 respectively. These fractions of the soils have considerably influence on the properties of the soils. According to the AASHTO soil classification system, soils at P1, P2, P3 and P4 are classified as A-2-5, A-7-6, A-24 , and A-3.

The moulding dry density and water content were the same as would be maintained during field compaction. Therefore, simulation to the worst moisture condition of the field was eminent. The specimens were kept submerged in water for two (2) days ( $24 \mathrm{hrs})$ before testing. This site has a natural moisture content of $14.5,13.0,16.5$, and 15.7 for the respective locations

Table 1. Summary of Geotechnical Soil's Properties of the Study Site

\begin{tabular}{|c|c|c|c|c|c|}
\hline & \multirow[t]{2}{*}{ Properties } & \multicolumn{3}{|c|}{ Quantity /description } & \multirow[b]{2}{*}{$\mathbf{P 4}$} \\
\hline & & P1 & $\mathbf{P 2}$ & P3 & \\
\hline & Gravel $(>4.75 \mathrm{~mm}), \%$ & 12.5 & 39 & 47 & 56.9 \\
\hline \multirow[t]{2}{*}{ Gradation } & Sand $(0.075-4.75 \mathrm{~mm}), \%$ & 58.4 & 20.8 & 22.8 & 17.46 \\
\hline & Silt and Clay $(<0.075 \mathrm{~mm}), \%$ & 29.1 & 40.2 & 30.2 & 25.64 \\
\hline \multirow[t]{5}{*}{ Classification } & AASHTO Soil Classification System & A-2-5 & A-7-6 & A-2-4 & A-3 \\
\hline & Unified Soil Classification System & Clayey Sand & Clayey soil & $\begin{array}{l}\text { Clayey } \\
\text { Sand }\end{array}$ & Fine sand \\
\hline & Colour & Dark brown & Grey & $\begin{array}{l}\text { Golden } \\
\text { brown }\end{array}$ & Brown \\
\hline & Natural Moisture Content (\%) & 14.5 & 13.0 & 16.5 & 15.7 \\
\hline & Specific Gravity & 1.76 & 16.5 & 1.76 & 2.54 \\
\hline \multirow{2}{*}{ Physical } & Liquid Limit (\%) & 40.8 & 42.9 & 57.9 & 58.9 \\
\hline & Plastic Limit (\%) & 22.6 & 20.3 & 28.9 & 29.0 \\
\hline \multirow{8}{*}{ Strength } & Plasticity Index (\%) & 18.2 & 22.6 & 29 & 29.9 \\
\hline & Grouping & ML, CL,OL & $\mathrm{MH}, \mathrm{CH}, \mathrm{OH}$ & $\mathrm{MH}, \mathrm{CH}, \mathrm{OH}$ & $\mathrm{MH}, \mathrm{CH}$ \\
\hline & Maximum Dry Unit weight (kN/m ) & 17.5 & 16.5 & 17.6 & 17.6 \\
\hline & Optimum Moisture Content (\%) & 14.7 & 16.5 & 14.5 & 13.0 \\
\hline & Permeability $(\mathrm{cm} / \mathrm{s})$ & $8.58 \times 10^{-5}$ & $3.91 \times 10^{-7}$ & $6.24 \times 10^{-3}$ & $7.33 \times 10^{-3}$ \\
\hline & Soaked CBR after $48 \mathrm{hrs}(\%)$ & 10 & 6 & 20 & 29 \\
\hline & $\begin{array}{l}\text { Unconfined Compressive Strength } \\
(\mathrm{kN} / \mathrm{m})\end{array}$ & 18.5 & 17.1 & 54.0 & 66.0 \\
\hline & Failure strength $(\%)$ & 12 & 12 & 12 & 8 \\
\hline
\end{tabular}

Since more than half the soil particles are coarser than $0.0075 \mathrm{~mm}$ size, the soil belongs to the group of "coarse grained soils". Also since the percentage of particle finer than $0.075 \mathrm{~mm}$ is more than $12 \%$ the soil could belongs to any one of the following groups: GM, GC, SM, SC. Assessing the respective plasticity characteristics of the soils, Casagrande standard mechanical device was used (Figure 2).

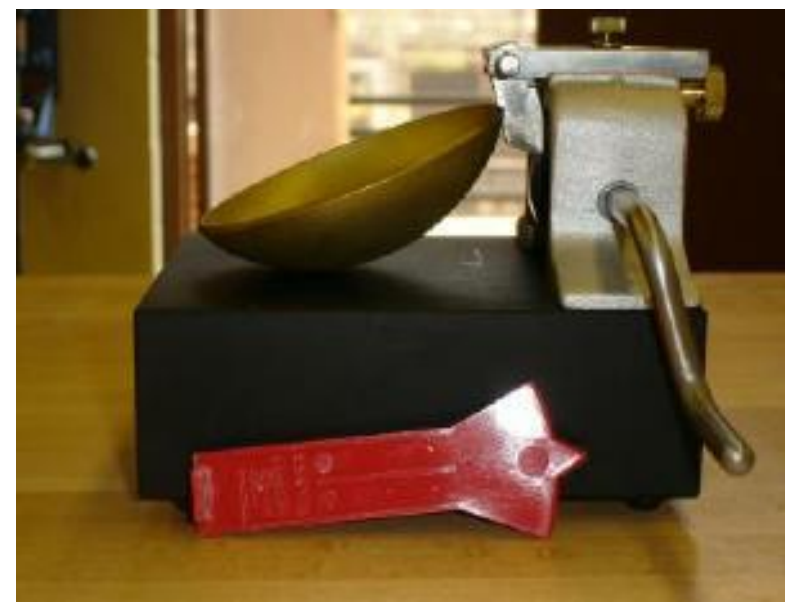

Fig 2. Showing Atterberg limit Casagrande mechanical device 
The soils have $\mathrm{W}_{\mathrm{L}}$ of $32.5,33.9,35.5$ and $36.0 \%$ in the representative traverse. Hence in the plasticity chart, (Atterberge limit) most the points fall above A-line (Fig 3). Therefore, the soil falls to SC group.

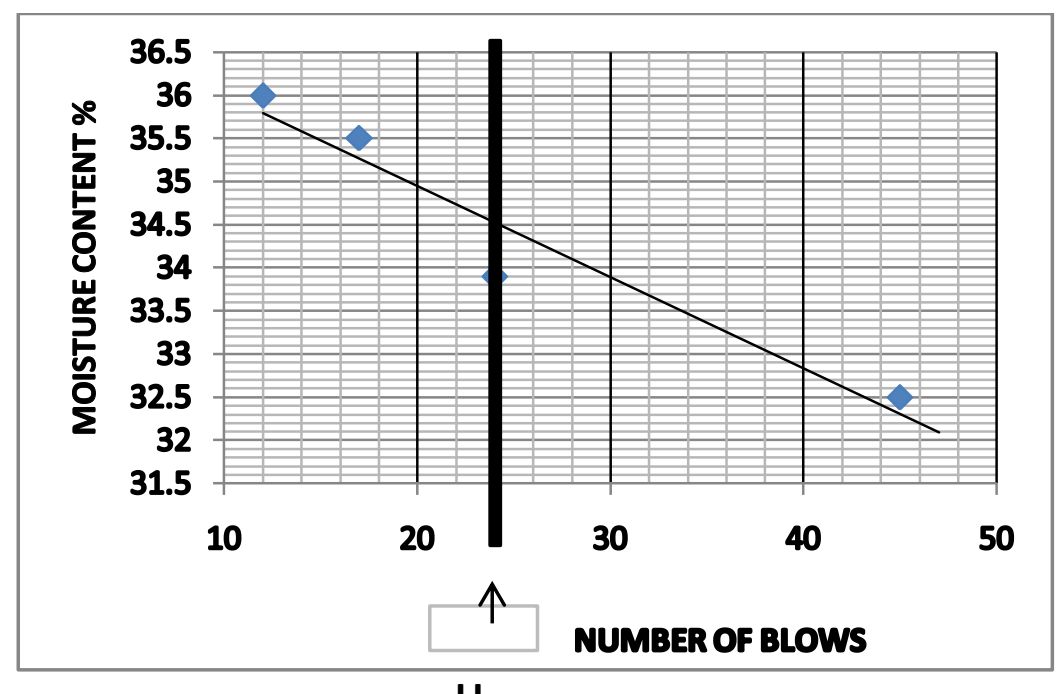

Fig 3. Atterberg model for soils of the study site

The liquidity index of the soil calculated indicating that the soil was in its plastic state (having intermediate strength and deforms like a plastic material) at the time of its collection. Figure 4 shows that the fines are predominantly clayey (except P4). The activity of the soil was determined to be 1.08 indicating that the soil is normally active.

Since the ultimate bearing capacity depends upon the angle of internal fraction $(\phi)$ and hence the penetration number $(\mathrm{N})$, it was related directly to the $\mathrm{N}$ at profiles $1,2,3$ and 4 from the existing surface, cohesion value of $25 \mathrm{kN} / \mathrm{m}^{2}$ was applied and the allowable bearing pressure of $18.5 \mathrm{kN} / \mathrm{m}^{2}$, $17.1 \mathrm{k} / \mathrm{Nm}^{2}, 54 \mathrm{k} / \mathrm{Nm}^{2}$, and $66 \mathrm{kN} / \mathrm{m}^{2}$ were obtained for profiles $1,2,3$ and 4 respectively by applying a factor of safety of 3.0. The higher the elevation, the higher the plasticity and the swelling potential; and the lower the bearing capacity and strength of the building subgrade.

The CBR test carried out on the compacted soil in a CBR mould of $150 \mathrm{~mm}$ (diameter) and $175 \mathrm{~mm}$ (height) provided with a detachable collar of $50 \mathrm{~mm}$ in height during the specimen preparation, enables a specimen of $125 \mathrm{~mm}$ deep to be obtained. The suitability of the sub-grade and materials used in sub-base and base of a flexible pavement was found to be workable (good) from $1 \mathrm{~m}$ depth down at locations 3 and 4 (P3 and P4) with CBR value of 20 and 29\% for the respective locations. Whereas locations 1 and 2 (P1 and P2) exhibited poor soils condition with high water table below $1 \mathrm{~m}$ depth and very low CBR values of 10 and 6\% respectively against 15\% (ASTM, 1979) for the respective area.

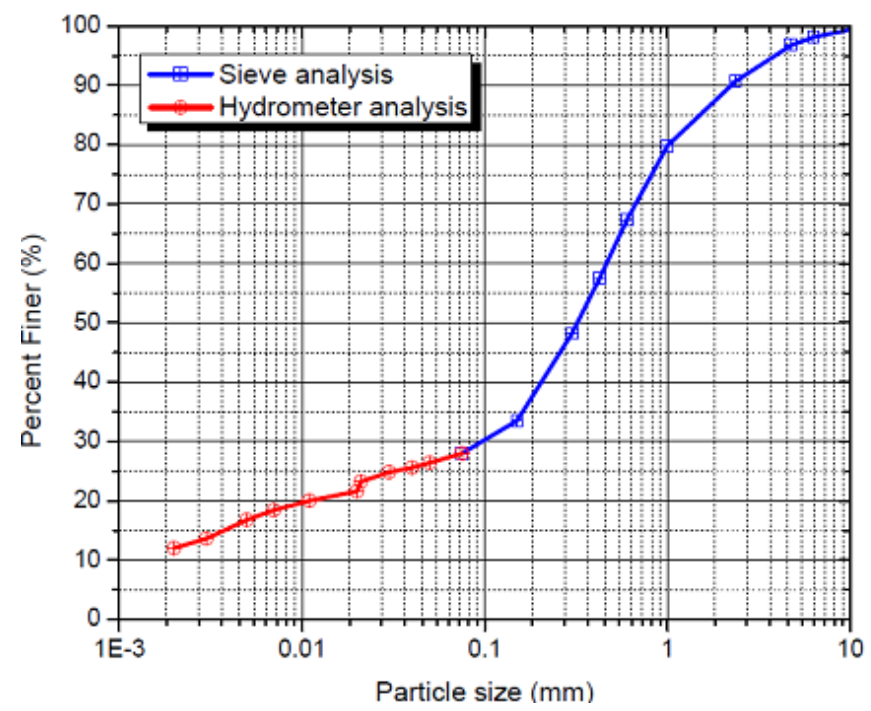

Fig 4. ASTM model predicting particle distribution of natural soil 
Specifically, the activity of the soil as determined indicated that, the soil is normally active, and the active zone varied with locations. According to the Central Building Research Institute, the area of the active zone for this site is limited to $0.75 \mathrm{~m}$ for locations 1 and 2 , and $3 \mathrm{~m}$ for locations 3 and 4 . The conditions of the water table considerably influenced the properties of soils at these four zones. The test results at P3 and P4 were found to be the best for foundation and engineering purposes, followed by soils at P1. The foundation on the soil should best be constructed during the hot season when the soil has shrink to its minimum level. A cushion of freely draining granular soil at P1 and P2 is advisable to place in the trench up to the base level of the footing and compacted, and then, the effect of the swelling on the foundation is reduced. Moreso, suitable arrangement should be made to drain the water away from the granular base during the rainy season.

\section{SITE EVALUATION AND RECOMMENDATION}

The surface waters received from non-tidal seasonal fresh water and rainwater flows to recharge the ground water that eventually moves through the over burden soil into the aquifer. Recharge depends on rainfall intensity and distribution and amount of surface runoff. Groundwater occurs under confined conditions at the site on account of the essentially clayey soil overlying the aquifer. The existence of this over burden-confining layer will determine whether or not groundwater contaminants introduced into the soil will reach the aquifer. During construction at the site, the protective soil vegetation is removed. Concentrated surface flow of rainwater rills the soil and changes the slope value, which eventually resulted in sheet/gully erosion observed in some locations. The cohesive and stiff consistency of the over lying clayey soil helps to limit the degree of environmental hazard.

Furthermore, observation and measurement made in the field and the result of the laboratory investigation were utilized in estimating the bearing proportion of the soil at the site. Our investigation revealed that the subsoil at the site is made up of soft dark brown and grey sandy clay at profiles 1 and 2 (located close to the water source), golden and light brown at profiles 3 and 4 respectively. The region within profiles 1 and 2 will require form of pretreatment prior to founding.

It is recommended that footings be placed on compacted fill of sand clay material at the region near water source (Profiles 1 and 2). The fill be placed with adequate control of moisture density and lift thickness with not less than 95\% standard Procter maximum density.

From the appearance of the site and base on its local topography, it is feared that when fully developed, surface water could be trapped within the site since it is rather flat within the region of profiles 1 and 2. Therefore external works services should pay earlier attention to the provision of surface water drain as may be conformed applicable. Services of competent material/structural engineer are recommended for guidance.

\section{B. Result of the Physico-chemical Properties (surface)}

Table 2. Physical and Chemical Properties of Surface Soils at Ekpenyong Atai

\begin{tabular}{|c|c|c|c|c|c|c|c|c|c|c|c|c|c|c|c|c|}
\hline Depth & $\mathrm{pH}$ & $\begin{array}{c}\text { Electrical } \\
\text { Cond. }\end{array}$ & THC & \multicolumn{2}{|c|}{ Org C Total N } & AV.P & $\mathrm{NO}_{3}^{-}$ & $\mathrm{K}^{+}$ & $\mathrm{Na}^{+}$ & $\mathrm{Ca}^{+}$ & $\mathrm{Mg}^{2+}$ & \multirow[t]{2}{*}{ CEC } & \multicolumn{2}{|c|}{\begin{tabular}{l|l} 
Sand & Silt
\end{tabular}} & Clay & \multirow{2}{*}{ Textural class } \\
\hline $\mathrm{cm}$ & & $\mu \mathrm{S} / \mathrm{cm}$ & $\mathrm{mg} / \mathrm{kg}$ & & & $\mu \mathrm{g} / \mathrm{g}$ & & & $\mathrm{cmo}$ & $1 / \mathrm{kg}$ & & & & $\%$ & & \\
\hline $0-15$ & 2.7 & 37 & 21.82 & 2.30 & 0.10 & 2.80 & 7.12 & 2.80 & 1.01 & 5.86 & 6.04 & 4.20 & 78 & 8 & 14 & Sandy loam \\
\hline $15-30$ & 2.3 & 21 & 18.45 & 2.01 & 0.08 & 1.90 & 6.62 & 1.80 & 0.80 & 6.38 & 7.04 & 3.60 & 78 & 9 & 13 & Sandy loam \\
\hline $0-15$ & 2.3 & 46 & 13.08 & 2.38 & 0.11 & 0.96 & 7.00 & 1.85 & 0.90 & 6.20 & 6.33 & 2.67 & 78 & 6 & 16 & Sandy loam \\
\hline $15-30$ & 2.1 & 40 & 26.18 & 2.08 & 0.09 & 1.92 & 5.50 & 2.81 & 1.01 & 6.60 & 8.12 & 3.18 & 78 & 10 & 12 & Sandy loam \\
\hline $0-15$ & 2.6 & 25 & 26.18 & 2.02 & 0.07 & 2.78 & 5.68 & 1.68 & 0.68 & 5.78 & 6.28 & 4.16 & 80 & 8 & 12 & Sandy loam \\
\hline $15-30$ & 2.6 & 43 & 26.18 & 1.98 & 0.09 & 1.98 & 4.34 & 0.81 & 0.58 & 4.20 & 5.40 & 5.20 & 79 & 7 & 14 & Sandy loam \\
\hline $0-15$ & 2.5 & 29 & 47.99 & 2.16 & 0.05 & 2.81 & 6.20 & 2.38 & 1.20 & 4.40 & 7.71 & 5.22 & 78 & 7 & 15 & Sandy loam \\
\hline $15-30$ & 2.3 & 14 & 56.72 & 1.50 & 0.10 & 1.48 & 4.32 & 0.52 & 0.58 & 1.32 & 5.33 & 6.28 & 80 & 10 & 10 & Sandy loam \\
\hline $0-15$ & 2.0 & 26 & 17.45 & 2.10 & 0.08 & 0.84 & 7.02 & 1.78 & 0.54 & 5.60 & 6.20 & 6.10 & 80 & 5 & 15 & Sandy loam \\
\hline $15-30$ & 2.1 & 39 & 8.72 & 2.11 & 0.07 & 1.04 & 6.24 & 0.60 & 0.48 & 1.98 & 2.48 & 4.78 & 77 & 8 & 15 & Sandy loam \\
\hline $0-15$ & 2.3 & 18 & 43.63 & 2.00 & 0.06 & 0.94 & 5.54 & 2.10 & 1.01 & 6.18 & 6.20 & 3.84 & 80 & 8 & 12 & Sandy loam \\
\hline $15-30$ & 2.1 & 19 & $\begin{array}{c}100.3 \\
4 \\
\end{array}$ & 1.78 & 0.05 & 1.92 & 6.14 & 0.40 & 0.30 & 5.68 & 5.84 & 3.90 & 78 & 8 & 14 & Sandy loam \\
\hline $0-15$ & 2.0 & 20 & 30.54 & 2.04 & 0.08 & 2.42 & 7.24 & 1.84 & 1.11 & 4.12 & 5.24 & 5.20 & 78 & 9 & 13 & Sandy loam \\
\hline $15-30$ & 2.2 & 34 & 13.08 & 1.87 & 0.06 & 0.96 & 6.12 & 0.54 & 0.50 & 3.44 & 4.24 & 6.10 & 77 & 8 & 14 & Sandy loam \\
\hline $0-15$ & 2.1 & 26 & 4.36 & 2.23 & 0.12 & 0.98 & 7.80 & 1.88 & 0.40 & 5.61 & 6.04 & 3.00 & 78 & 6.5 & 16 & Sandy loam \\
\hline $15-30$ & 2.2 & 18 & 30.54 & 1.79 & 0.09 & 1.04 & 5.62 & 0.86 & 0.78 & 3.42 & 4.10 & 4.37 & 79 & 10 & 11 & Sandy loam \\
\hline
\end{tabular}

$\mathrm{THC}=$ Total Hydrocarbon, Org. $\mathrm{C}=$ Organic Carbon, $\mathrm{C} / \mathrm{N}$ ratio $=$ Carbon-Nitrogen ratio, Av.P. = Available Phosphorus, $\mathrm{CEC}=$ Cation Exchangeable Capacity 
Table 3. Summary of Laboratory Sub-Soil Test Results at various depths.

\begin{tabular}{|c|c|c|c|c|c|c|c|c|c|c|c|}
\hline \multirow[b]{2}{*}{$\begin{array}{c}\text { Profile } \\
\text { No. }\end{array}$} & \multirow[b]{2}{*}{$\begin{array}{c}\text { Sample } \\
\text { depth }\end{array}$} & \multirow[b]{2}{*}{ Soil Type } & \multicolumn{4}{|c|}{$\begin{array}{l}\text { Grain Size Distribution } \\
\text { (Percent Passing Sieves) }\end{array}$} & \multicolumn{3}{|c|}{ Atterberg Limits } & \multirow[t]{2}{*}{$\begin{array}{c}\text { Permeability } \\
(\mathrm{cm} / \mathrm{sec} .)\end{array}$} & \multirow{2}{*}{$\begin{array}{c}\text { Classification } \\
\text { Unified Soil } \\
\text { Classification } \\
\text { System } \\
\text { (U.S.C.S) }\end{array}$} \\
\hline & & & $\begin{array}{c}\text { NO. } 4 \\
(4.75 \mathrm{~mm})\end{array}$ & $\begin{array}{c}\text { No.10 } \\
2.00 \mathrm{~mm}\end{array}$ & $\begin{array}{c}\text { No. } 40 \\
0.42 \mathrm{~mm}\end{array}$ & $\begin{array}{l}\text { No. } 200 \\
0.075 \mathrm{~mm}\end{array}$ & $\mathbf{L L}(\%)$ & PL(\%) & PL(\%) & & \\
\hline \multirow{2}{*}{ P1 } & $0.5 \mathrm{~m}$ & Silty Clay & 92.0 & 84.0 & 80.0 & 80.0 & 75.0 & 16.6 & 7.9 & $1.65 \times 10^{-8}$ & $\mathrm{CL}$ \\
\hline & $0.75 \mathrm{~m}$ & Clay Sand & 38.0 & 31.0 & 29.0 & 22.0 & 12.2 & 5.8 & 6.4 & $1.45 \times 10^{-5}$ & $\mathrm{SC}$ \\
\hline $\mathrm{P} 2$ & $0.5 \mathrm{~m}$ & $\begin{array}{l}\text { Gravelly } \\
\text { Sand }\end{array}$ & 26.0 & 22.0 & 18.0 & 15.0 & - & - & $\begin{array}{c}\text { Non } \\
\text { Plastic }\end{array}$ & $1-36 \times 10^{-2}$ & SW \\
\hline \multirow{3}{*}{$\mathrm{P} 3$} & $1 \mathrm{~m}$ & Silty Clay & 90.0 & 87.0 & 81.0 & 76.0 & 15.8 & 7.2 & 8.6 & $1.72 \times 10^{-8}$ & $\mathrm{CL}$ \\
\hline & $5 \mathrm{~m}$ & Clay Sand & 35.0 & 33.0 & 31.0 & 30.0 & 12.4 & 6.0 & 6.4 & $1.60 \times 10^{-5}$ & $\mathrm{SC}$ \\
\hline & $3 \mathrm{~m}$ & $\begin{array}{l}\text { Gravelly } \\
\text { Sand }\end{array}$ & 32.0 & 29.0 & 18.0 & 15.0 & - & - & $\begin{array}{l}\text { Non } \\
\text { plastic }\end{array}$ & - & SW \\
\hline \multirow{3}{*}{$\mathrm{P} 4$} & $1 \mathrm{~m}$ & Silty Clay & 92.0 & 86.0 & 81.0 & 75.0 & 16.6 & 7.9 & 8.7 & $1.70 \times 10^{-8}$ & $\mathrm{CL}$ \\
\hline & $2 \mathrm{~m}$ & Clay Sand & 32.0 & 31.0 & 30.0 & 28.0 & 12.2 & 6.2 & 6.0 & $1.50 \times 10^{-5}$ & SC \\
\hline & $3 \mathrm{~m}$ & $\begin{array}{l}\text { Gravelly } \\
\text { Sand }\end{array}$ & 22.0 & 18.0 & 15.0 & 10.0 & - & - & $\begin{array}{l}\text { Non } \\
\text { plastic }\end{array}$ & - & SW \\
\hline
\end{tabular}

The physico-chemical properties of soils of the study area are presented in Table 2 . Typically the soils are loose, coarse texture with $78-80 \%$ sandy fractions having single grain structure from unconsolidated materials of recent alluvial deposits (P1 and P2). The soils are strongly acid in reaction with $\mathrm{pH}$ values between 4.8 and 5.8 which could be attributed to leaching of the basic cations to lower depth.

Organic carbon content ranged from moderately low $1.50 \%$ to high $2.38 \%$ due probably to high surface litter and vegetation cover. Total nitrogen ranged between $0.05-0.12 \%$, the low levels could be attributed to the heavy losses through leaching which is responsible also for the very low levels of available phosphorus $(0.96-2.81 \mu \mathrm{g} / \mathrm{g})$. Nitrate levels are very low $(4.33-7.80 \mu \mathrm{g} / \mathrm{g})$ due to the combined effects of intensive cultivations, poor nitrification and high leaching processes occurring in the soils. This is evidenced in the moderate/high carbon-nitrogen ratio $(15-43)$ indicating that mineralization and humification process will be slow.

The soils are moderate to high in exchangeable bases. Potassium, calcium and magnesium were dominant while sodium is low for Nigerian soils (Odu, et al, 1985). The moderate to high levels of exchangeable bases found in the soils could be attributed to the nature of the parent materials.

The cation exchange capacity is very low $(2.67-6.28 \mathrm{cmol} / \mathrm{kg})$ indicating the type of clay minerals. The results revealed that fertility ratings of the soils are moderately low when compared with fertility indices of soils in Nigeria (Ayotade and Fagade, 1986). Total hydrocarbon (oil) concentration in the soil is low indicating very low hydrocarbon contamination. The amount detected could be attributed to biogenic sources.

The study revealed from the logs a uniform correlation in the four (4) profiles of an overburden brown, medium grained, stiff consistency silty clay soil with thickness of 6-8 meters. This is underlain by 1 to $3 \mathrm{~m}$ depth of brown, medium grained clayey sand. Below this stratum is the aquiferous brown, coarse-grained, gravelly sand to the profile depths beyond $0.75 \mathrm{~m}(\mathrm{P} 1), 0.5 \mathrm{~m}(\mathrm{P} 2)$ and $3 \mathrm{~m}(\mathrm{P} 3$ and $\mathrm{P} 4)$. Grain size analysis involved dry sieving on field obtained samples.

Results obtained from the grain size analysis of samples from the boreholes show that the fine to medium grained soils of silty clay and clayey sand have moderate to high fines passing sieve No. 200 (22 to $75 \%$ ) while the coarse grained gravelly sands have much less silty/clay fractions (10 to 15\%). The fine grained nature of the clays mean that fluid flow through them will be slow, as the number of particles per unit area is relatively small and void spaces are fewer. The clayey soils therefore have relatively low permeabilities on account of their fine grains.

Atterberg limits (also known as consistency limits) expresses the water absorbing and adsorbing ability of fine grained (Fig 5), cohesive soil, with the plasticity index indicating the range of water content, through which the soil remains plastic. The results show a low plasticity range (6 to 8.7\%) for the cohesive soils, while the gravelly sands are non-plastic (Table 3). Atterberg limit tests are applicable only to fine grained, cohesive soils. The low values of plasticity indices of the plastic soils are an indication of their low water retaining capacity.

The soils were classified under the unified soil classification system as SW, SC and CL implying well-graded gravelly sand, clayey sands and low plasticity clays (Table 2). The permeability test results reveal low values of $1.65 \times 10^{-8}$ to $1.60 \times 10^{-5} \mathrm{~cm} \mathrm{sec}^{-1}$. for the clayey soils. The gravelly sand 
display a high coefficient of permeability of $1.36 \times 10^{-2} \mathrm{~cm} \mathrm{sec}^{-1}$. Infiltration capacity of soil depends on the permeability, degree of saturation, vegetation and amount and duration of rainfall (Todd, 1980).

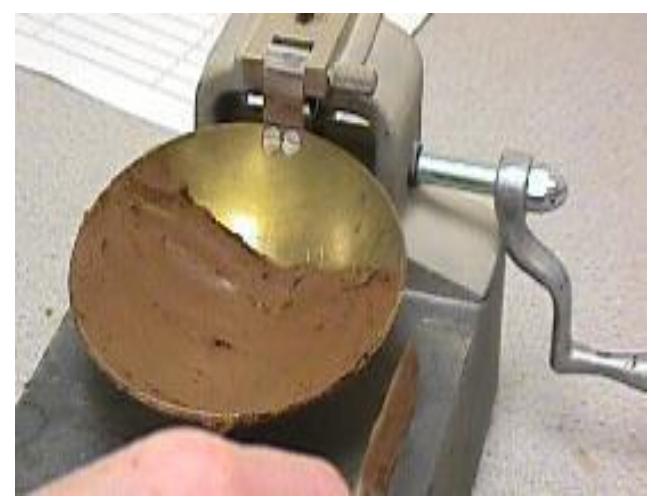

Fig 5. Experiment showing water absorbing and adsorbing ability of fine grained

\section{CONCLUSION}

The study revealed that the soils are loose, coarse texture with $78-80 \%$ sandy fractions having single grain structure from unconsolidated materials of recent alluvial deposits. The soils are strongly acid in reaction with $\mathrm{pH}$ values between 4.8 and 5.8 which could be attributed to leaching of the basic cations to lower depth. Organic carbon content ranged from moderately low $1.50 \%$ to high $2.38 \%$ due probably to high surface litter and vegetation cover. The low levels of total nitrogen could be attributed to the heavy losses through leaching which is responsible also for the very low levels of available phosphorus $(0.96-2.81 \mu \mathrm{g} / \mathrm{g})$. Nitrate levels are very low $(4.33-7.80 \mu \mathrm{g} / \mathrm{g})$ due to the combined effects of intensive cultivations, poor nitrification and high leaching processes occurring in the soils, evidenced in the moderate/high carbon-nitrogen ratio $(15-43)$ indicating slow mineralization and humification process.

The physical properties of the sub-soils were determined and used as indices of their infiltration capacity and classification. Profiles dug to the maximum depth of $3 \mathrm{~m}$ reveal fine-grained, stiff consistency silty clay overlying medium grained clayey sand. Beneath this is the aquiferous coarse gravelly sand. The aquifer is confined and this condition may help to seal off the lower strata and aquifer from pollutants. However, environmental hazards that may occur at the site may include sheet erosion and flooding.

\section{REFERENCES}

[1] A.S.T.M. (1979). Annual Book of America Society for Testing and Materials Standards, 1289 Philadelphia, ASTM Tech. Publication, 630pp.

[2] Allen, J.R.L. (1965). Late Quaternary Niger Delta and adjacent areas Sedimentary Environment and Lithofacies. AAPG Bulletin. 49: 547-600.

[3] Apata T.G. Samuel, K.D. and Adeola, A.O. (2009). Analysis of Climate change perception and Adaptation among Arable Food Crop Farmers in south Western Nigeria. Paper Presented at the Conference of International Association of Agricultural Economics pp. 2-9.

[4] Ayotade, K.A and Fagade, S.O (1986). Nigeria's program for wetland rice production and rice research. In: A.S.R Juo and J.A Lowe (eds): The Wetlands and Rice in Sub-Saharan Africa. Ibadan Nigeria: IITA, pp 201-60.

[5] Bonilla, C.A, and Vidal K.L. (2011). Rainfall erosivity in Central Chile. Journal of Hydrology 410(1-2):126-33.

[6] B.S. 1377 (1975). Methods of test for soils for civil engineering purposes. British Standard Institution (BSI), London, 1377pp.

[7] Essien, O.E. and Essien, I.A (2013). Effect of disturbed soil properties on gully growth/soil loss at underground drainage construction site, Uyo. Journal of Earth Sciences and Geotechnical Engineering 3(1):27-9.

[8] Ferro, V. and Porto,P. (1999). A comparative study of rainfall erosivity estimation for southern Italy and southeastern Australia. Hydrological Sciences Journal 44(1):3-23. 
[9] Klute,A. (1986). Methods of Soil Analysis Part 1, Physical and Mineralogical Methods. American Society of Agronomy, Madison, WI.

[10] Loch, R.J. and Roeswell, C.J. (1992). Laboratory methods for measurement of soil erodibility(K factor) for Universal soil Loss Equation. Aust J Soil Res 30:233-40.

[11] Mckenzie, N., Coughlan, K. and Cresswell, H. (2002). Soil physical measurement and interpretation for land evaluation. Australia: CSIRO Publishing.

[12] Muzik, I. (2002). A first- order analysis of the climate change effect on flood frequencies in a subalpine watershed by means of hydrological rainfall-runoff model. Journal of Hydrology 267:65-73.

[13] Nearing, M.A., Jetten, V. and Baffaut, C. (2005). Modelling response of soil erosion and runoff to changes in precipitation and cover. Catena 61:131-54.

[14] Nelson, D.W. and SommersL.E. (1996).Total carbon, organic carbon and organic matter. Soil Science Society of America and American Society of Agronomy 6775. SSA Book Series, No.5: Methods of Soil Analysis. Part 3.

[15] Nwankwoala, H.O.and Amadi, A.N. (2014). Geotechnical investigation of sub-soil and rock characteristics in parts of Shiroro-Muya-Chanchaga area of Niger State, Nigeria. International Journal of Earth Sciences and Engineering 6(1):8-17.

[16] Odu, C.T.I., Esuruoso, O.F., Nwoboshi, L.C.and Ogunwale, J.A. (1985). Environmental study of the Nigerian Agip Oil Company operational areas. In: Proceedings of the soils and fresh water vegetation conference, Milan (Italy).

[17] Ogban, P.I. and Obi J.C. (2010). The relation between natural fallow and soil quality in Akwa Ibom State, Southeastern Nigeria. Nigerian Journal of Agriculture, Food and Environment 6(3\&4):34-43.

[18] Ozor, N. (2009). Understanding climate change. Implications for Nigerian Agriculture, Policy and Extension. Paper presented at the national conference on climate change and the Nigerian Environment. Organized by the Department of Geography, University of Nigeria, Nsukka, June 29-July 2.

[19] Oke, S.A., Okeke, O.E., Amadi, A.N., Onoduku, U.S. (2009). Geotechnical properties of the sub-soil for designing shallow foundation in some selected parts of Chanchaga area, Minna, Nigeria.

[20] Parry, M.L., Canziani, O.F. and Palutikof, J.P. (2007). Climate Change: Impacts, Adaptation and Vulnerability. Contribution of Working Group 11 to the Fourth Assessment Report of the Intergovernmental Panel on Climate Change. Cambridge University Press, Cambridge.

[21] Rashid, H. (1982). Urban flood problem in Benin City, Nigeria: Natural or Manmade? Malaysian Journal of Tropical Geography 6:17-30.

[22] Renard, K.G., Foster G.R. andMcCool, D.K. (1997). Predicting Soil Erosion by Water. A Guide to Conservation Planning with the Revised Universal Soil Loss Equation (RUSLE). Agriculture Handbook No. 703, USDA, Washington, DC.

[23] Schofield, N. and Telford, T. (2006). Disturbed soil properties andgeotechnical Design, ISBN 07277-2982-9.

[24] Sluk-Ak. (1989). Physical background, soils and landuse and ecological problems.Technical Report of Task Force on Soil and Landuse Survey, Akwa Ibom State, Government Printer.

[25] Smith, B. and M. Skinner. (2002). Adaptation options in Agriculture to climate change: a typology, mitigation and adaptation strategies for global change. African Journal of Agriculture and Resource Economics 3(5):78-82.

[26] Suresh, R. (2006). Soil and Water Conservation Engineering. Delhi, India: Standard Publishers Distributors.

[27] Udo, E.J. and Sobulo, R.A. (1981). Acid sands of Southern Nigeria. Soil Science SOC. Nigeria. SpecPubl Monogr1:165.

[28] Udo-Inyang U.C. and Edem, I.D. (2012). Analysis of rainfall trends in Akwa ibom State, Nigeria. Journal of Environment and Earth Science 2(8).

[29] Wischmeir, D.H. and Smith, D.D. (1978). Predicting Rainfall Erosion Losses: A Guide to Conservation Planning. Agriculture Handbook No. 537, US Gov. Print. Office, Washington DC. 